\title{
感性ロボットのための感情領域を用いた表情生成
}

\section{Face Generation Using Emotional Regions for Sensibility Robot}

\begin{tabular}{|c|c|}
\hline $\begin{array}{l}\text { 後藤 みの理 } \\
\text { Minori Gotoh }\end{array}$ & $\begin{array}{l}\text { 名古屋工業大学 } \\
\text { Nagoya Institute of Technology } \\
\text { mgotoh@juno.ics.nitech.ac.jp }\end{array}$ \\
\hline $\begin{array}{l}\text { 加納 政芳 } \\
\text { Masayoshi Kanoh }\end{array}$ & $\begin{array}{l}\text { 中京大学 } \\
\text { Chukyo University } \\
\text { mkanoh@life.chukyo-u.ac.jp, http://www.st.chukyo-u.ac.jp/mkanoh }\end{array}$ \\
\hline $\begin{array}{l}\text { 加藤 昇平 } \\
\text { Shohei Kato }\end{array}$ & $\begin{array}{l}\text { 名古屋工業大学 } \\
\text { Nagoya Institute of Technology } \\
\text { shohey@ics.nitech.ac.jp }\end{array}$ \\
\hline $\begin{array}{l}\text { 國立 勉 } \\
\text { Tsutomu Kunitachi }\end{array}$ & $\begin{array}{l}\text { 大同工業大学 } \\
\text { Daido Institute of Technology }\end{array}$ \\
\hline $\begin{array}{l}\text { 伊藤 } \\
\text { Hidi英則 }\end{array}$ & $\begin{array}{l}\text { 名古屋工業大学 } \\
\text { Nagoya Institute of Technology } \\
\text { itoh@ics.nitech.ac.jp, http://www-itolab.ics.nitech.ac.jp }\end{array}$ \\
\hline
\end{tabular}

keywords: sensibility robot, entertainment robot, emotional space, auto-associative neural network, expressions of emotion.

\section{Summary}

We think that psychological interaction is necessary for smooth communication between robots and people. One way to psychologically interact with others is through facial expressions. Facial expressions are very important for communication because they show true emotions and feelings. The "Ifbot" robot communicates with people by considering its own "emotions". Ifbot has many facial expressions to communicate enjoyment. We developed a method for generating facial expressions based on human subjective judgements mapping Ifbot's facial expressions to its emotions. We first created Ifbot's emotional space to map its facial expressions. We applied a five-layer auto-associative neural network to the space. We then subjectively evaluated the emotional space and created emotional regions based on the results. We generated emotive facial expressions using the emotional regions.

\section{1.はじめに}

近年，家庭で人と共生するロボットの開発が盛んであ り，さまざまなロボットか開発されている[村瀬 01, 黑木 02, 黑木 03, 神田 03, Fujita 00].家庭用ロボットは, 人 間の生活環境に適応する必要があり，また，人とコミュ ニケーションをとるためのインタフェースを備えている ベきである . 人間同士のコミュニケーションでは , 言語 情報のみならず非言語情報のやりとりも重要な意味を持 つ [辻 97] . 非言語情報のうちでも特に，感情や情動など の心理的情報を人間とロボットとのコミュニケーション に取り入れる研究は, 盛んに行われている.例えば，[小 林 94] は, ロボットが人の感情を認識し，光れに対する 反応を人に分かりやすいように表示伝達するためのアク ティブ・ヒューマン・インタフェースを提唱し，この表示 伝達手段としての顔ロボットの構造・機構と表情表出の 制御について報告している. [柴田 00] は, 自律的に心や 感情を持つかのように行動し, 人と身体的に相互作用す
るペットロボットを開発しており，この相互作用によっ て , 人に楽しみや安らぎなどの精神的効果を与える可能 性を示している .このように , 人間とロボットとのコミュ ニケーションにおいても感情や情動が議論されるように なってきた .このような中で, 本研究は, ロボットの感情 や情動の表出を人間とのコミュニケーションに導入する ことにより，2 者の円滑な対話の実現を目標としている．

感情や情動の伝達において重要な役割を果たすものの 1 つとして , 顔表情があげられる . 人間同士のコミュニ ケーションでは, 怒りの表情を示すことで相手を威嚇し， 喜びの表情を示すことで相手に好意を伝えることができ る.このように顔表情は，感情状態を如実に表す．ロボッ トと人間とのコミュニケーションにおいても同樣に，口 ボットが内部感情に対応した表情を生成・表出すること ができれば，人間とのコミュニケーションはよりスムー ズになると考えられる .

表情を表出可能な顔ロボットとしては, SAYA[原 04] や kismet[Breazeal 99] などがある . SAYA は人間の顔 
や皮膚の質感を実装しており，人間の表情を忠実に表す． 現在 SAYA は，受付ロボットとして実用化されている . kismet は頭部をデフォルメした顔ロボットで, 強調され た眉，目，口，耳の動きを使って表情を作り出す.いずれ も表情によって自らの感情状態を表現し，人とのコミュ ニケーションの円滑化を図るロボットである．

我々は感性会話型ロボット ifbot を開発している $[\mathrm{BDL}$, Ohshiro 03, Tamura 03, Kato 04, Ijuin 04, 柴田 04, Kanoh 04c] . ifbot は, 話者の発話内容を認識し, 自ら の感情を表現しながら会話を行うロボットである . ifbot は, 自らの感情を表現するために数十種類の表情を持ち， これらの表情を表出しながら会話する . 人間とのコミュ ニケーションはロボットに限らず, CG のエージェント を用いても可能であると考えられる．しかし，ロボット は物理的実体を有するため，立体感や実在感，空間共有 感などによって感性的因子をより良く表出できると考え られる [原 04].特に, ifbot は, 複雑な表情表出機構に よって樣々な表情が表出できるため, 感性的因子の表出 に向いているといえる.本稿では，CGではなく ifbotと 人とのコミュニケーションにおける ifbot の表情による 感情表現について評価する。

これまで, ifbot の感情を考慮に入れた表情生成とし て，感情空間を用いて表情を滑らかに変化させる手法が 提案されている [Kanoh 04d] .この文献では，恒等写像 学習を用いて感情空間を構築しているが, 空間内での感 情と表情のマッピングを十分に評価しておらず，人間の 感性に見合った表情生成を行えているとはいえなかった． そこで本稿では, 人間の主観に基づいて感情空間を評価 し，評価結果に基ついた表情生成を行うことを提案する。 まず，表情と感情とをマッピングするために，恒等写 像学習を利用して感情空間を構築する，つぎに，感情空 間を用いて表情を生成し，これを主観的に評価する。光 して，弚の結果に基づいて感情空間内に感情的な表情を 表出するための領域 (感情領域) を設定する . 光して , 感 情領域を用いて表情生成したときの印象の変化を実験的 に評価し，感情領域を用いることの有効性を示す．

\section{2. ifbot}

図 1 に ifbot の概観を示す . ifbot は身長 $45 \mathrm{~cm}$ ，重さ $9.5 \mathrm{~kg}$ であり，2 つの腕を有し，車輪によって移動する．

図 2 にifbotの表情表出機構の概要を示す . ifbot は表 情表出のために 10 のモータおよび 101 の LED を持つ. モ一タは, 首を 2 軸 (同図 $\theta_{N 1}, \theta_{N 2}$ ), 左右の目を 2 軸 (同図 $\theta_{E 1}^{(L)}, \theta_{E 2}^{(L)}, \theta_{E 1}^{(R)}, \theta_{E 2}^{(R)}$ ), 左右のまゔ氵をを 2 軸 (同 図 $\left.\theta_{L 1}^{(L)}, \theta_{L 2}^{(L)}, \theta_{L 1}^{(R)}, \theta_{L 2}^{(R)}\right)$ の方向へ動作させる. LED は, 頭部 $\left(L_{H}\right)$, 口部 $\left(L_{M}\right)$, 目部 $\left(L_{E}\right)$, 㚘部 $\left(L_{C}\right)$, 涙 部 $\left(L_{T}\right)$ ，耳部に配置され，頭部 3 色 (橙, 緑，赤)，口 部 1 色 (橙), 目部 3 色 (緑, 赤, 青), 頬部 1 色 (赤), 淚部 1 色 (青)，耳部 1 色 (橙) を発色する。これらの

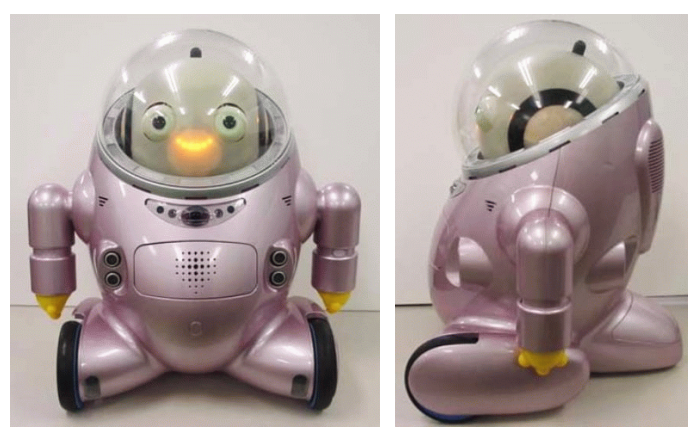

図 1 ifbot の概観

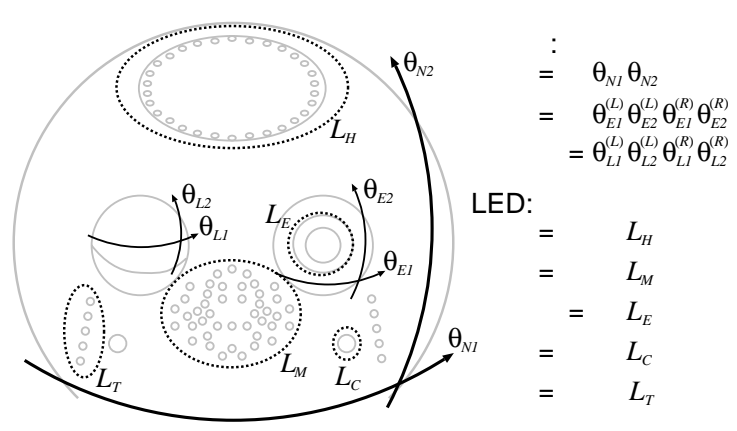

図 2 ifbot の表情表出機構

機構により, ifbot は表情豊かなコミュニケーションを行 うことができる .

\section{3. 感情空間の構築}

ifbot の表情特徵を感情空間にマッピングするために 恒等写像学習 [Bishop 95] を使用する . 恒等写像学習は， 中間層が絞り込まれた砂時計型ネットワークを持ち，入 出力層に同一の学習データを与え, 学習させる枠組であ る、恒等写像学習を行うことで, 学習データに含まれる 内部構造が中間層に獲得される [清水 90] . また , ニュー ラルネットの汎化性能より, 基本表情データの学習のみ で中間的な表情の生成が可能である .これまでも恒等写 像ネットワークは表情の分析・合成システムに利用され ている [上木 94, 坂口 97] .

本稿では, 図 3 に示す 5 層で構成される恒等写像学習 ネットワークを使用する . このネットワークは, 第 3 層 のユニット数が入出カユニット数より少ない構造を持つ. 5 層型の恒等写像ネットワークは, 3 層型のネットワーク に比へて優れた非線形写像能力を発揮することが可能で ある [片山 89] . このネットワークでは, 学習によって， 第 3 層に入力データを特徵づける情報が抽出される. 本 稿では, 第 3 層に抽出される特徵空間を感情空間として 利用する。

ネットワークのユニット数は $15,45,2,45,15$ とし た．すなわち第 3 層に抽出される感情空間は 2 次元とな る. 表情データの内部構造を 2 次元に圧縮することによ 


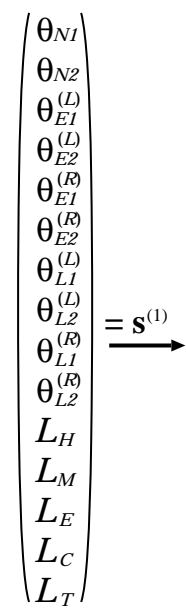

図 3 感情空間の構築

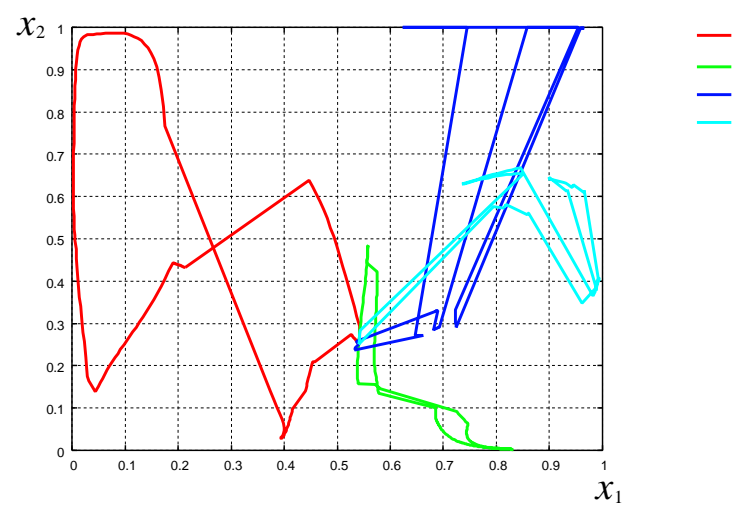

図 5 感情空間

り，特徵空間が視覚的に表現される．これは感情空間の 評価や領域分割のために適している .

入力データは, 10 のモータ出力值と, 光れぞれの部位 の LED の出力值をパターン分類したデータとした .

$$
\begin{aligned}
\boldsymbol{s}^{(1)}= & \left(\theta_{N 1}, \theta_{N 2}, \theta_{E 1}^{(L)}, \theta_{E 2}^{(L)}, \theta_{E 1}^{(R)}, \theta_{E 2}^{(R)}, \theta_{L 1}^{(L)},\right. \\
& \left.\theta_{L 2}^{(L)}, \theta_{L 1}^{(R)}, \theta_{L 2}^{(R)}, L_{H}, L_{M}, L_{E}, L_{C}, L_{T}\right)^{T} .
\end{aligned}
$$

学習データには, 怒り, 喜び, 悲しみ, 驚きの 4 つの表情 データを使用した . 各表情データは事前に行われたアン ケート [Kanoh 04d, 加納 04a, 加納 04b] において, 怒 り，喜び，悲しみ，驚きの表情として高い支持率を得た

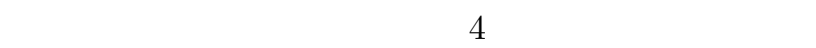
表情変化を示す．

構築された感情空間を图 5 に示す．感情空間上の $4 つ$ の軌跡は, 学習に用いた表情データの軌跡を表す. 赤が 怒り, 緑力驚き, 青か悲しみ, シアンが喜びである. 弚れ 光れの感情の軌跡が感情空間内で分類されていることが わかる.次節では，この感情空間を主観的に評価し，各 感情を表出する領域を感情空間内に設定する．

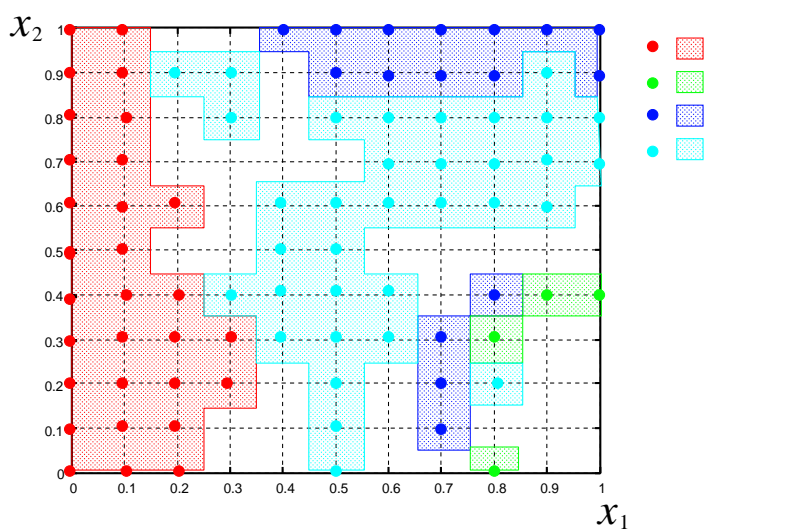

(a) 支持率 $50 \%$ 以上

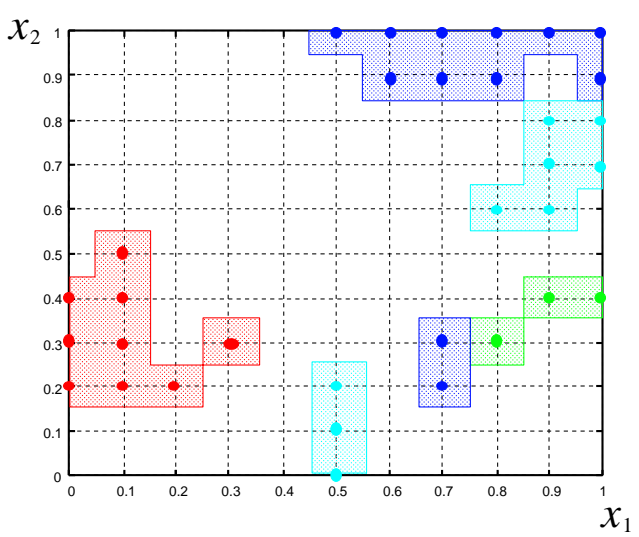

(b) 支持率 $80 \%$ 以上

図 6 アンケート結果

\section{4. 感情領域の設定}

人間の主観的評価に基づいて感情領域を設定する . こ れにはアンケートを用いた . アンケートには，121の表 情を用いた .これらの表情の抽出は以下の手順で行う .

まず，感情空間を 0.0 から 1.0 まで 0.1 刻みで格子状 に区切り，各交点を抜き出す．つぎに，各交点の座標点 を恒等写像学習ネットワークの第 3 層に入力し, 第 5 層 から表情パラメータを出力させる .この表情パラメータ から表情を生成する. 回答者には乥れ光れの表情を基本 6 感情 [Ekman 75] と分類不能のいずれかに類別しても らう. 20 人に対してアンケートを行った .

図 6 にアンケートの結果を示す．同図において，怒 りと支持された座標点を赤い点, 驚きと支持された座標 点を緑の点, 悲しみと支持された座標点を青の点, 喜び と支持された座標点をシアンの点で表している.图 6(a)

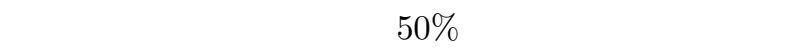
点, (b) が $80 \%$ 以上の支持率を得た座標点を示している.

ここで, アンケートの結果において，50\%以上 $80 \%$ 末 満の支持率を得た座標点と $80 \%$ 以上の支持率を得た座標 点に着目する .これらの座標点周りの一定範囲では同一 の感情を表出していると考え，50\%以上 $80 \%$ 未満の支持 率を得た座標点の周りを弱い感情表出領域， $80 \%$ 以上の 


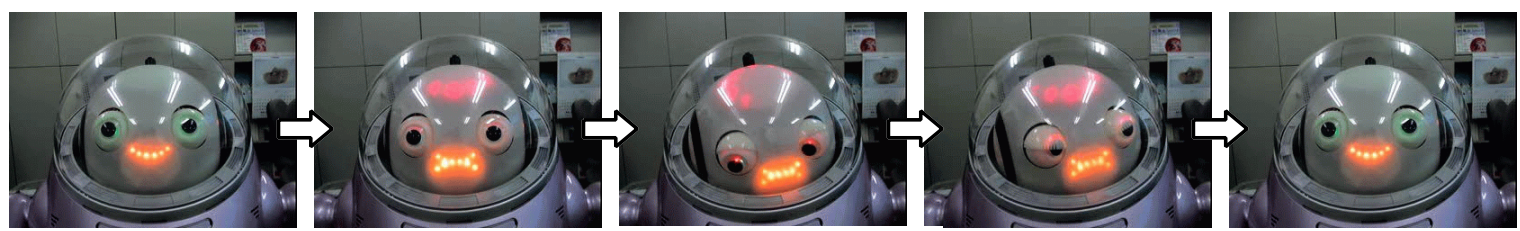

怒り (支持率 90\%)
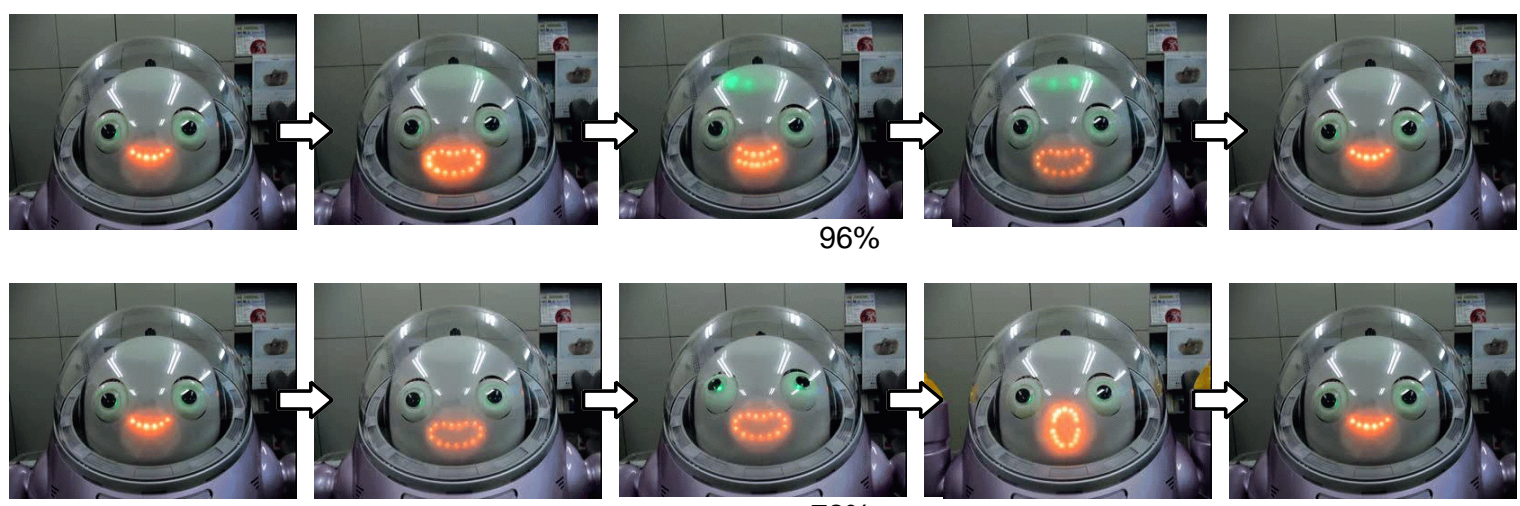

驚き（支持率 72\%)

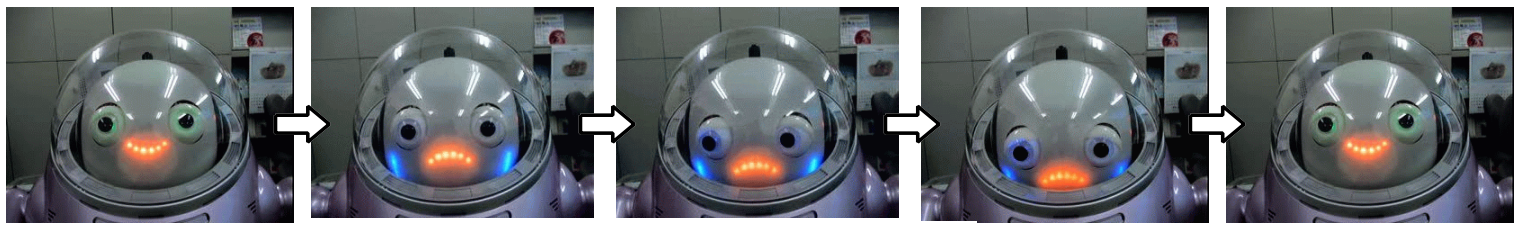

悲しみ (支持率 86\%)

図 4 表情データ

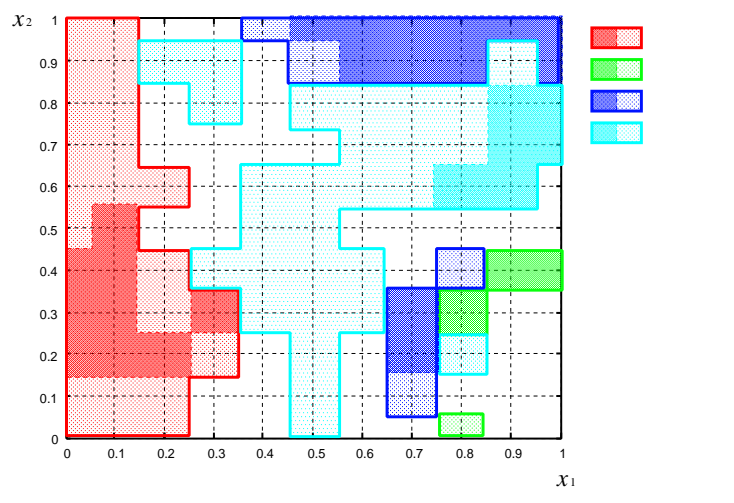

図 7 主観評価に基づく感情領域

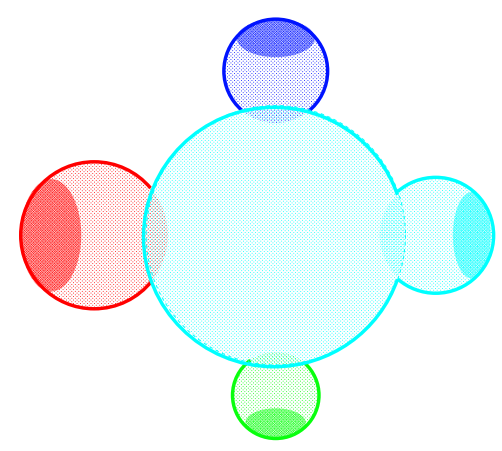

図 8 感情領域の模式図

\section{5. 感情領域を用いた表情生成}

支持率を得た座標点の周りを強い感情表出領域とする． これに基づき, ifbotの感情的表情表出のための感情領域 を図 7 のように設定する。同図において，濃色か強い 感情表出領域（強領域），淡色か弱い感情表出領域（弱 領域)である.感情領域を模式化したものを図 8 に示す． ifbot の感情領域では, 喜びの弱領域が感情空間の中心付 近にあり，感情的な表情が光の周りに分布する . ifbot で は, エンタテインメント性向上のために, 喜びの弱領域 を平静状態のときに使用する . 平静状態でも弱い喜びを 表出することにより，人にリラックス感を与えることが できると考えられる .この感情領域を用いて, ifbot の内 部感情に沿った表情生成を行う. ifbot は数十種類の作り込み表情を持っている .これら の表情により, 感情の表出や, 意思の表示, 感覚にともな う表情表現, 歌うなどのエンタテインメント表現などが 実現されている.しかし，これらは平静時の表情からあ る表情へと変化し, 平静時の表情で終了する時系列デー タである . すなわち，ある 1 つの感情を長時間継続して 表出することや, 感情の変化に伴って表情をなめらかに 変化させることができない，乥こで，内部感情を適切に 表現するために感情領域を用いる .

ロボットが感情を継続して表出する場合，ある一定の 表情で静止するよりも，表情に適度な動きを伴う方が自 然である. 本稿では, 自然な表情表出のために表出表情 


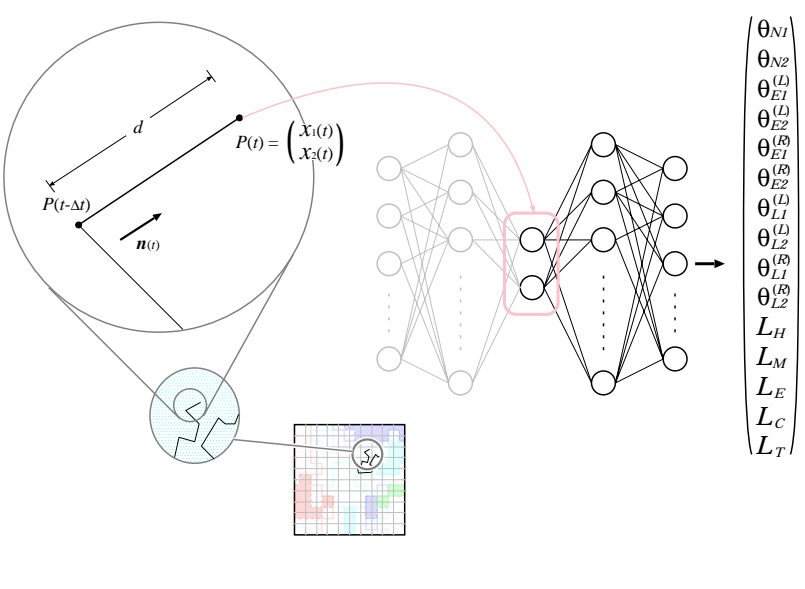

図 9 軌跡の作成

にゆらぎを持たせることを考える．图 9 に表情生成の概 要を示す． 感情空間上の時刻 $t$ における座標点 $P(t)=$ $\left(x_{1}(t), x_{2}(t)\right)^{T}$ を恒等写像学習ネットワークの第 3 層に 入力し, 表情を生成する . 座標点 $P(t)$ は, 以下の手続き で決定される .

（1）ゆらぎ值の決定

以下の式に基づき, 時刻 $t$ におけるゆらぎ值 $X_{i}(t)$ を決定する。

$$
X_{i}(t)=\left\{\begin{array}{r}
X_{i}(t-\Delta t)+2 X_{i}(t-\Delta t)^{2} \\
\left(0 \leq X_{i}(t-\Delta t)<0.5\right) \\
X_{i}(t-\Delta t)-2\left(1-X_{i}(t-\Delta t)\right)^{2} \\
\text { (otherwise). }
\end{array}\right.
$$

ただし， $\Delta t$ は時間ステップであり，t- $\Delta t$ は 1 時間 ステップ前を表す . ここでは, 感情空間が 2 次元で あるため，2つのゆらぎ值 $X_{1}(t) ， X_{2}(t)$ を考える。

(2) 方向べクトルの決定

手順 (1) で求めたゆらぎ值から，座標点の移動方向 $\boldsymbol{n}(t)=\left(n_{1}(t), n_{2}(t)\right)^{T}$ を決定する.

$$
\boldsymbol{n}(t)=\frac{\boldsymbol{u}(t)}{|\boldsymbol{u}(t)|} .
$$

ただし，

$$
\boldsymbol{u}(t)=\left(\begin{array}{l}
X_{1}(t)-0.5 \\
X_{2}(t)-0.5
\end{array}\right) .
$$

(3) 座標点の決定

点 $P(t-\Delta t)$ を $\boldsymbol{n}(t)$ の方向に一定距離 $d$ だけ移動 させ，これを点 $P(t)$ とする

$$
P(t)=\left(\begin{array}{c}
x_{1}(t-\Delta t)+d n_{1}(t) \\
x_{2}(t-\Delta t)+d n_{2}(t)
\end{array}\right) .
$$

以上の手続きを繰返すことにより，表情を継続表出する

\section{6. 実 験}

感情領域に軌跡を描く際に，強領域を利用すると感情 強度の高い表情が生成でき，弱領域を利用すると強度の 低い表情が生成できると考えられる．また，時間ステッ プ $\Delta t$ を調整することでも，生成される表情の印象か変化 すると考えられる．これらを確認するために，本稿では 2 つの実験を行う . まず, 感情強度の異なる感情領域を 用いたときに生成される表情の印象の変化を調べる (時 間ステップは固定とする）．つぎに，時間ステップを変 化させたときに，印象がどのように変化するかを調べる．

\section{$6 \cdot 1$ 感情領域の違いによる 評価}

感情領域を用いることで, 感情表出の強さの異なる表 情を生成できることを確認する．图 7 にあるすべての感 情の強領域と弱領域から表情を生成する.生成された 8 種類の表情についてアンケートする . アンケートに用い た表情例を図 10 に示す. 図 10(a) は悲しみの強領域か ら生成した表情で, 図 10(b) は同弱領域から生成した表 情である．アンケートは，8 種類の表情をランダムな順 序で回答者に提示することで行う．回答者には光れ光れ の表情を基本 6 感情 [Ekman 75] と分類不能のいずれか に類別してもらう . 基本 6 感情のいずれかとした場合は， 弚の表情が表出している感情の強度を 5 段階て評価する。 感情強度が最も低いものを 1 点, 最も高いものを 5 点と して評価点数をつける. 20 人を対象にしてアンケートし た .パラメータは， $\Delta t=100(\mathrm{~ms}), d=0.05$ とした .

表 1 にアンケート結果を示す. 強領域の表情には感情 名の末尾に S , 弱領域の表情には W を記した . 同図中， 各カラムの左の数值は評価点数, 右の数值 (括弧内の数 値) は支持者数である.評価点数が高いと感情表出の度 合が強いといえ，支持者数が多いと感情の識別率が高い といえる. 分類不能の場合は, 5 段階評価をしていない のて評価点数はない，感情領域上の 4 表情の結果を見る と，強領域の評価点数のほうが弱領域の点数よりも高い ことがわかる.また，弚れ光れの表情に対応する感情の 支持率は $50 \%$ 以上であることがわかる .これらより，感 情領域の強弱を用いて，感情表出の度合を変化させるこ とができると考えられる．以下に，光れ光れの感情に対 する考察を示す．

怒りの表情では, 評価点数, 感情の識別率ともに高く, ifbot における怒りの表情は識別しやすいといえる . 弱領 域 (怒り W) の表情では, 嫌悪の支持者数か増加する. ifbot においては怒りの表出度合が小さくなると嫌悪に評 価される傾向があることを示している .

喜びでは, 弱領域の表情 (喜びW) において，嫌悪の 支持者数が多く，また兴の評価点数が高い．この表情で は，まぶたの開きが小さくなる．これを眉をひ光めたよ うな表情と評価し，嫌悪に類別する回答者が多かった．

悲しみにおいては, 強領域の表情 (悲しみ $\mathrm{S}$ ) と弱領 


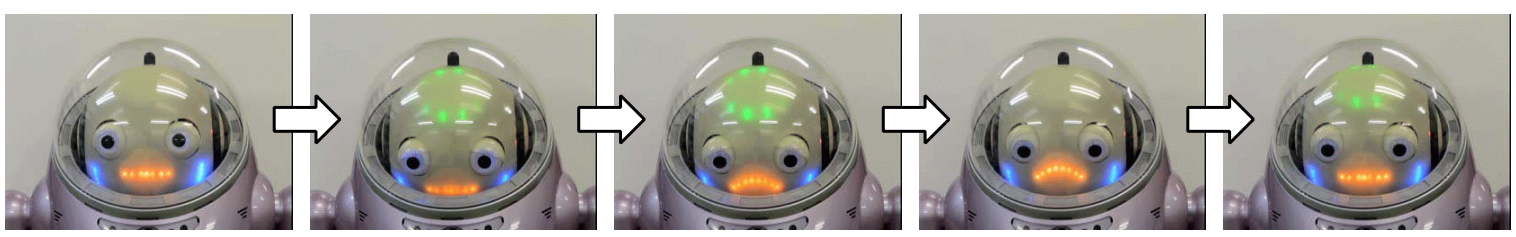

(a) 悲しみ (強領域)

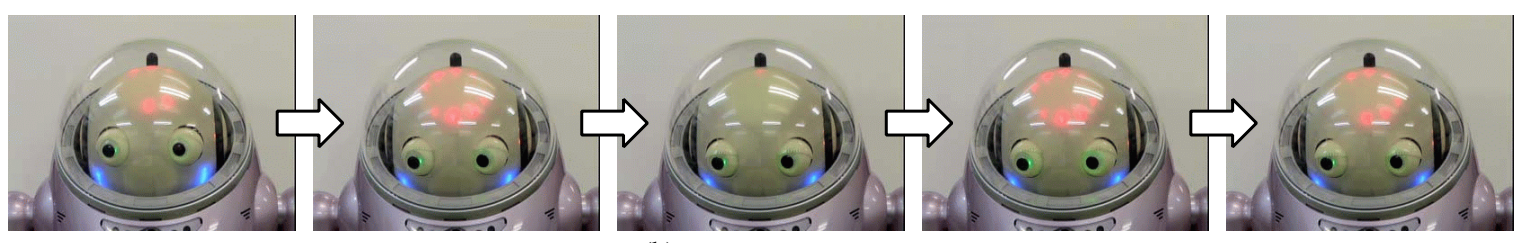

(b) 悲しみ (弱領域)

図 10 アンケートに用いた表情例 (悲しみ)

表 1 アンケート結果 : 評価点数 (支持者数)

\begin{tabular}{|c|c|c|c|c|c|c|c|c|c|c|}
\hline & \multicolumn{2}{|c|}{ 怒り } & \multicolumn{2}{|c|}{ 喜び } & \multicolumn{2}{|c|}{ 悲しみ } & 驚き & 嫌悪 & 恐れ & 分類不能 \\
\hline 怒り S & 85 & (19) & 0 & & 0 & & 0 & $4 \quad(1)$ & 0 & (0) \\
\hline 怒り W & 71 & (16) & 0 & & 0 & & 0 & $\begin{array}{ll}16 \quad(4) \\
\end{array}$ & 0 & (0) \\
\hline 喜びS & 0 & & & (16) & 7 & (3) & 0 & 0 & (1) & (0) \\
\hline 喜びW & 0 & & & (10) & 2 & (1) & 0 & $\begin{array}{ll}20 & (7)\end{array}$ & (1) & (1) \\
\hline 悲しみ $\mathrm{S}$ & 0 & & 4 & $(1)$ & & (16) & 0 & 0 & 14 & (0) \\
\hline 悲しみ W & 0 & & 3 & (1) & 45 & (16) & 0 & $4 \quad(1)$ & $(2)$ & (0) \\
\hline 驚き S & 1 & (1) & 4 & $(2)$ & 0 & & $\begin{array}{ll}28 & (9) \\
\end{array}$ & (1) & (1) & (6) \\
\hline 驚き W & 0 & & 3 & (2) & 0 & & (9) & (2) & 15 & (2) \\
\hline
\end{tabular}

表 2 表情の变化速度

\begin{tabular}{|c|r|c|}
\hline & $\Delta t(\mathrm{~ms})$ & $d$ \\
\hline \hline Fast 条件 & 100 & 0.05 \\
\hline Slow 条件 & 200 & 0.05 \\
\hline
\end{tabular}

域の表情 (悲しみW) の支持者数は変化しないが, 評価 値が減少している．これは，悲しみ $\mathrm{S}$ のほうが感情を強 く表出していることを示している．

驚きの表情では, 全体的に支持者数が少なく他の感情 との混同が多くなる．しかし，驚きを支持した回答者の 評価点数は, 強領域の表情と弱領域の表情とでは差が見 られた。

\section{$6 \cdot 2$ 速度の違いによる 評価}

表情の変化する速度が, 印象にどのように影響するか を調べる . 感情ごとに明確な差が見られれば，感情表出 の度合を変化させることができると考えられる．感情ご との 4 領域において , 時間ステップ $\Delta t$ を変化させて表情 を生成する．このとき，感情領域の強弱は区別せず，同 一の軌跡を利用する. 表情の変化条件を表 2 に示す．ア ンケートでは, 表情変化の速い表情 (Fast 条件) で生成 された表情と，表情変化の遅い表情 (Slow 条件) で生成 された表情とを同時に提示し，どちらが感情をより強く 表しているかを選択してもらう．なお，各表情がどの感 情に属するかはあらかじめ伝えた . アンケートは 15 人 を対象にして行った . アンケートに用いた表情例を図 11
表 3 アンケート結果

\begin{tabular}{|c||r|r|}
\hline 表情データ & Fast 条件 & Slow 条件 \\
\hline \hline 怒り $\mathrm{A}$ & $\mathbf{1 2}$ & 3 \\
\hline 怒り $\mathrm{B}$ & $\mathbf{1 1}$ & 4 \\
\hline 怒り $\mathrm{C}$ & $\mathbf{1 1}$ & 4 \\
\hline 喜び $\mathrm{A}$ & $\mathbf{8}$ & 7 \\
\hline 喜び $\mathrm{B}$ & $\mathbf{1 2}$ & 3 \\
\hline 喜び $\mathrm{C}$ & $\mathbf{1 3}$ & 2 \\
\hline 悲しみ $\mathrm{A}$ & 4 & $\mathbf{1 1}$ \\
\hline 悲しみ $\mathrm{B}$ & 4 & $\mathbf{1 1}$ \\
\hline 悲しみ $\mathrm{C}$ & 2 & $\mathbf{1 3}$ \\
\hline 驚き $\mathrm{A}$ & $\mathbf{1 1}$ & 4 \\
\hline 驚き $\mathrm{B}$ & $\mathbf{1 1}$ & 4 \\
\hline 驚き $\mathrm{C}$ & $\mathbf{1 2}$ & 3 \\
\hline
\end{tabular}

に示す.

表 3 にアンケート結果を示す．同表は，ある感情領域 内の軌跡を利用して, Fast 条件下で生成した表情と Slow 条件下で生成した表情の支持者数を示している.

怒りと驚きの表情では, Fast 条件下で生成された表情 がより感情強度が高いと評価された . 喜びにおいても, 喜 び A には大きな差異が見られないものの，喜び B およ び喜び C では，Fast 条件下で生成された表情がより感 情強度が高いと評価された．怒り，喜び，驚きの表情で は, 気分が高揚した状態, すなわち表出速度が速い方が 

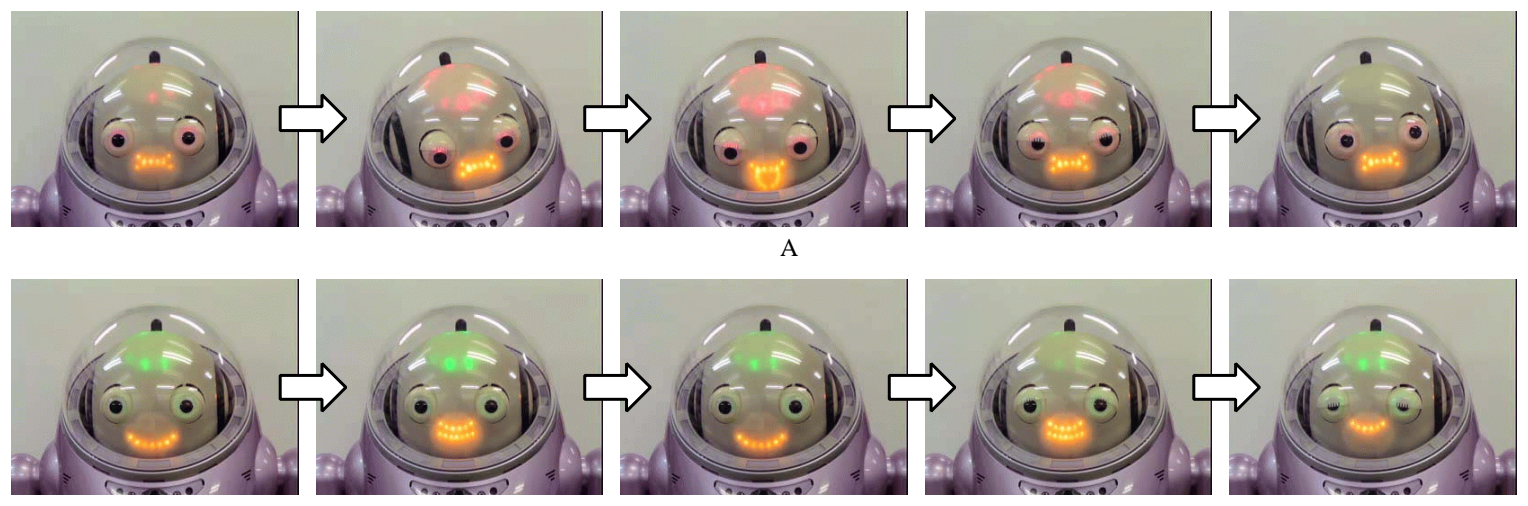

喜びA

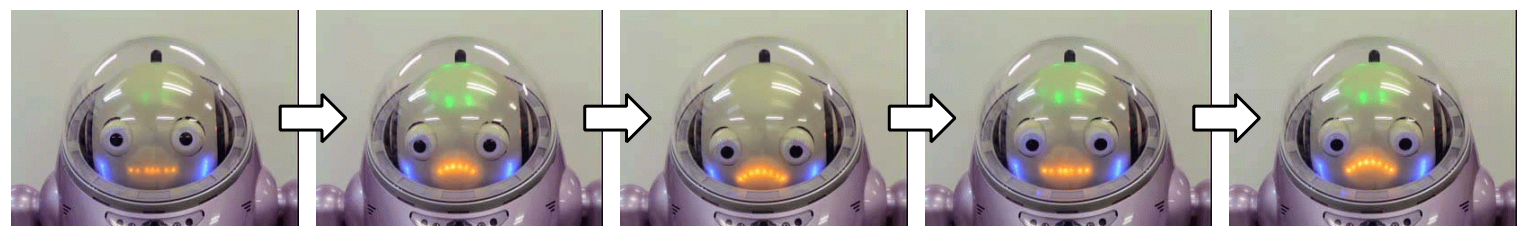

悲しみA

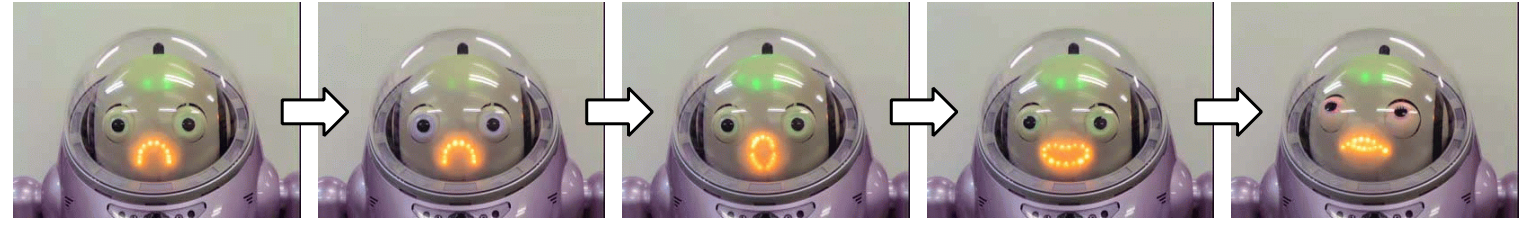

驚き $\mathrm{A}$

図 11 アンケートに用いた表情例

感情の表出度合が強くなると考えられる．

悲しみの表情では, Slow 条件下で生成された表情がよ り感情強度が高いと評価された．悲しみのような気分が 消沈した感情を表情に表出する際には，表出速度が遅い 方が感情の表出度合が高くなると考えられる．

本実験の結果から, 表情の変化速度を変えることで, 感 情表出の度合を変化させることができるといえる．

\section{7.お わりに}

本稿では, 恒等写像学習を用いて ifbot の表情を感情 空間にマッピングすることで, ifbot の表情特性を抽出す ることを試みた．乥して，得られた感情空間を人間の主 観で評価し，感情領域を設定した．さらに，感情領域を 利用した表情生成手法を提案した。

実験では，感情領域の設定の強弱により，人に与える 印象が変化することを確認した . また, 表情の変化速度で も感情表出の強度変化を確認した . 本手法により, ifbot の内部感情と対応した表情の生成や，表出される感情の 強度を考慮した表情生成を行うことができると考えられ る.また, ある 1 つの感情を長時間継続して表出するこ とや，感情の変化に伴って表情をなめらかに変化させる ことも可能である. 本稿では, ifbot の感情表出に関し て評価したのみであり，一般性は保証されない．しかし， 本研究は, 今後登場するロボットの感情表出に関する研 究開発の一助となることが期待できる .
今後の課題としては，発話による感情表現手法の確立 と，発話と表情とを利用した感情表出があげられる．

謝辞

ifbot は株式会社ビジネスデザイン研究所の製品企画・ 総合プロデュースのもと，特に，形状デザイン，表情制 御メカニズムはブラザー工業株式会社，および，表情制 御ソフトはブラザー工業株式会社，ロボス株式会社，名 古屋工業大学が共同開発した . 関連各位に感謝する.

本研究の一部は文部科学省科学研究費補助金基盤 (C) 課題番号 17500143 , 若手研究 (B) 課題番号 17700160 , および, 栢森情報科学振興財団の助成のもとで行われた .

\section{$\diamond$ 参 考 文 献 $\diamond$}

[BDL] Business Design Laboratory Co. Ltd.: Communication Robot "ifbot",http://www.ifbot.net

[Bishop 95] Bishop, C. M.: Neural Networks for Pattern Recognition, Oxford University Press (1995)

[Breazeal 99] Breazeal, C. and Scassellati, B.: A contextdependent attention system for a social robot, In Proceedints of the Sixteenth International Joint Conference on Artificial Intelligence (IJCAI99), pp. 1146-1151 (1999)

[Ekman 75] Ekman, P.: Unmasking the Face, Prentice-Hall (1975)

[Fujita 00] Fujita, M., Kitano, H., and Doi, T.: Robot Entertainment, In A.Druin and J.Hendler (2000)

[原 04] 原 文雄, 小林 宏: 顔という知能, 共立出版 (2004)

[Ijuin 04] Ijuin, K., Kanoh, M., Kato, S., and Itoh, H.: A Research on Ifbot's Facial Expressions and Its Color Effect, Japan-Korea Joint Symposium on Emotion \& Sensibility, 
in $C D-R O M(2004)$

[神田 03] 神田 真司, 村瀬 有一, 藤岡 和夫 : インターネット対応 型ロボット : MARON-1, Fujitsu, Vol. 54, No. 4, pp. 285-292 (2003)

[加納 04a] 加納 政芳, 吉田 宏徳, 加藤 昇平, 伊藤 英則 : 感情空 間を用いたロボットの表情生成と兴の解析, 第 18 回人工知能学 会全国大会論文集, in CD-ROM (2004)

[加納 04b] 加納 政芳, 吉田 宏德, 加藤 昇平, 伊藤 英則 : 感性会 話型ロボット「ifbot」の表情制御の感情空間へのマッピング, 第 66 回情報処理学会全国大会論文集, 分冊 4, pp. 77-78 (2004)

[Kanoh 04c] Kanoh, M., Kato, S., and Itoh, H.: Analyzing Emotional Space in Sensitivity Communication Robot "ifbot", The 8th Pacific Rim International Conference on Artificial Intelligence, pp. 991-992 (2004)

[Kanoh 04d] Kanoh, M., Kato, S., and Itoh, H.: Facial Expressions Using Emotional Space in Sensitivity Communication Robot "ifbot", IEEE/RSJ International Conference on Intelligent Robots and Systems, pp. 1586-1591 (2004)

[片山 89] 片山 泰男, 大山公一：自己組織逆伝播二ューラルネッ 卜の諸特性, 1989 信学春季全大 SD-1-14 (1989)

[Kato 04] Kato, S., Ohshiro, S., Itoh, H., and Kimura, K.: Development of a Communication Robot Ifbot, The 2004 IEEE International Conference on Robotics and Automation (ICRA), pp. 697-702 (2004)

[小林 94] 小林 宏, 原 文雄, 内田 豪, 大野宗久:アクティブ・ヒュー マン・インタフェース $(\mathrm{AHI})$ のための顔ロボットの研究, 日本 ロボット学会誌, Vol. 12, No. 1, pp. 155-163 (1994)

[黑木 02] 黑木, 石田, 長阪, 山口: 高度統合運動制御機能を有す る小型二足歩行エンターテイメントロボット SDR-4X，日本ロ ボット学会創立 20 周年学術講演会, p. 1C34 (2002)

[黑木 03] 黑木, 三上, 長阪, 加藤, 宮本, 森平, 永野, 山口 : 高 度モーションエンターテインメント機能を有する小型二足歩行 ロボット SDR-4XII, 第 21 回日本ロボット学会学術講演会, p. 1A21 (2003)

[村瀬 01] 村瀬 有一, 安川 裕介, 境 克司, 植木 美和 : 研究用小 型ヒューマノイドの設計, 第 19 回ロボット学会学術講演会予行 集, pp. 789-790 (2001)

[Ohshiro 03] Ohshiro, S., Kato, S., Watabe, K., Yamakita, T., Kimura, K., and Itoh, H.: A Vision-based Talker Distinction System of Human-Robot Communication, International Symposium on Micromechatronics and Human Science, pp. 73-76 (2003)

[坂口 97] 坂口 竜己, 山田 寛, 森島 繁生 : 顔画像を基にした 3 次 元感情モデルの構筑と炎の評価, 電子情報通信学会論文誌, Vol. J80-A, No. 8, pp. 1279-1284 (1997)

[柴田 00] 柴田 崇徳：感情を持つかのような人エシステム, 日本 ファジィ学会誌, Vol. 12, No. 6, pp. 752-761 (2000)

[柴田 04] 柴田 寛, 加納 政芳, 加藤 昇平, 伊藤 英則 : 感情指定パ ラメータによる感情を持つロボット「ifbot」の表情生成制御手 法の提案, 第 6 回日本感性工学会大会予稿集, p. 261 (2004)

[清水 90] 清水 誠司, 片山 泰男, 森島 繁生 : 恒等写像を実現する ニューラルネットの特性について, 信学 '90 春大, Vol. D-472, (March 1990)

[Tamura 03] Tamura, K., Kato, S., Yamakita, T., Kimura, K., and Itoh, H.: A System of Dialogical Mental Health Care with Sensibility Technology Communication Robot, International Symposium on Micromechatronics and Human Science, pp. 67-71 (2003)

[辻 97] 辻 三郎：感性の科学一感性情報処理へのアプローチ, サイ エンス社 (1997)

[上木 94] 上木 伸夫, 森島 繁生, 山田 寛, 原島 博 : 多層二ュ一 ラルネットによって構成された感情空間に基づく表情の分析 . 合成システムの構築, 電子情報通信学会論文誌, Vol. J77-D-II, No. 3, pp. 573-582 (1994)

〔担当委員 : 三輪 和久〕

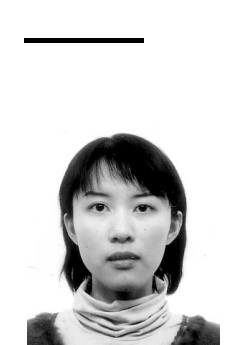

者 紹 介

後藤 みの理

2005 年名古屋工業大学工学部知能情報システム学科卒業 同年同大学大学院工学研究科博士前期課程進学 . 知能 · 感 性ロボティクスに興味を持つ.

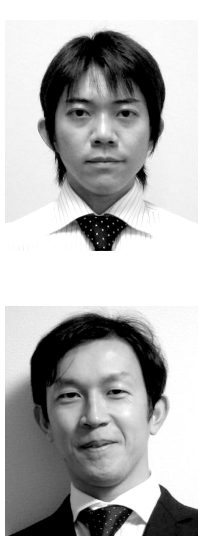

加納 政芳(正会員)

2004 年名古屋工業大学大学院工学研究科博士後期課程修 了. 同年中京大学生命システム工学部講師. 博士 (工学) 知能・感性ロボティクス，探索問題などに興味を持つ。電 子情報通信学会, 情報処理学会, 日本ロボット学会, 電気 学会, 日本感性工学会各会員.

\section{加藤 昇平 (正会員)}

1998 年名古屋工業大学大学院工学研究科博士後期課程修 了.同年豊田工業高等専門学校助手, 1999 年同講師. 2002 年名古屋工業大学講師, 2003 年同助教授. 博士 (工学) 知識推論・探索処理, 並列探索問題, 画像処理, 知能・感 性ロボティクスなどに興味を持つ。電子情報通信学会 , 情 報処理学会, 日本ロボット学会, 画像電子学会各会員.

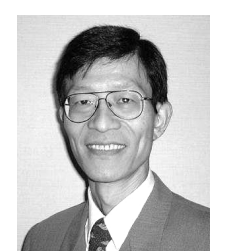

\section{國立勉}

1975 年名古屋大学大学院修士課程修了. 1975 年日本電 信電話公社横須賀研究所. 2001 年大同工業大学教授. 博 士 (工学) . システムプログラム , 知的プログラミングな どに興味を持つ。電子情報通信学会, 情報処理学会 , 日本 感性工学会, IEEE-CS, ACM 各会員.

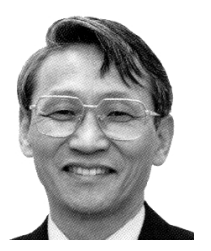

伊藤 英則 (正会員)

1974 年名古屋大学大学院工学研究科博士課程電気電子専 攻満了. 工学博士号取得. 1974 年日本電信電話公社横須 賀研究所勤務. 1985 年 (財) 新世代コンピュータ技術開 発機構出向. 1989 年名古屋工業大学大学院教授、情報工 学専攻. 数理言語理論, 計算機ネットワーク通信, OS , 人 工知能などの研究開発に従事. 電子情報通信学会, 情報処 理学会, 日本ロボット学会, 形の科学会, 日本感性工学会 各会員 